\title{
PENGEMBANGAN PERANGKAT KERAS ELEKTRONIK LOG BOOK PENANGKAPAN IKAN BERBASIS LAYAR SENTUH
}

\author{
DEVELOPMENT OF ELECTRONIC FISHING LOG BOOK HARDWARE BASED TOUCH \\ SCREEN
}

\author{
Hadhi Nugroho dan Agus Sufyan \\ Pusat Pengkajian dan Perekayasaan Teknologi Kelautan dan Perikanan \\ Jl. Pasir Putih I Ancol Timur, Jakarta \\ E-mail: hadhinugroho@gmail.com
}

Diterima tanggal: 9 Maret 2014, diterima setelah perbaikan: 24 Juli 2014, disetujui tanggal: 28 Juli 2014

\begin{abstract}
ABSTRAK
Pusat Pengkajian dan Perekayasaan Teknologi Kelautan dan Perikanan (P3TKP) sejak 2011 telah mengembangkan teknologi elektronik log book penangkapan ikan, yaitu perangkat keras yang memiliki fungsi input data tangkapan ikan secara elektronik dan dilengkapi dengan fungsi rekam jejak kapal. Pada 2011 telah dikembangkan perangkat keras elektronik log book berbasis keypad. Namun, alat ini memiliki beberapa kelemahan, yaitu semua data harus dimasukkan ke dalam alat dengan menggunakan kode angka, ukuran displai LCD kecil, serta ukuran alat yang relatif besar. Untuk itu, pada 2012 dikembangkan perangkat keras elektronik log book berbasis layar sentuh. Kemudian pada 2013 dilakukan penyempurnaan dan pengembangan perangkat keras elektronik log book berupa perubahan ukuran layar sentuh menjadi lebih besar, penambahan power bank sebagai baterai cadangan untuk suplai tenaga listrik alat, penggunaan antena GSM internal, serta proses pengunduhan data dari alat ke dalam komputer. Dari proses perancangan perangkat keras, telah dihasilkan prototipe perangkat keras elektronik log book. Kemudian dilakukan pengujian untuk mengetahui keberhasilan dalam perancangan perangkat keras. Pengujian tersebut terdiri dari pengujian ARM dan LCD layar sentuh, pengujian pengiriman data, pengujian daya tahan baterai, serta pengujian di lapangan (di atas kapal nelayan). Hasil pengujian tersebut di antaranya adalah data tangkapan ikan dan data rekam jejak kapal secara otomatis dapat dilihat di situs web, daya tahan baterai selama 13 jam, serta data hasil inputan yang dapat diunduh secara manual. Dari hasil pengujian diperoleh hasil bahwa perangkat keras yang dibuat telah berhasil bekerja dengan baik. Pengembangan ini diharapkan mampu memberikan kemudahan kepada nelayan dalam menggunakan elektronik log book sehingga diharapkan dapat menggantikan penggunaan log book secara manual dengan kertas.
\end{abstract}

Kata kunci: elektronik log book, perangkat keras, layar sentuh, ARM, baterai

\begin{abstract}
Research and Development Center of Marine and Fisheries Technology (P3TKP) since 2011 has developed an electronic log book for fisheries, which has a function to input the fisheries catches data electronically and equipped with a track record function from the vessel. In 2011, P3TKP has developed an electronic log book with keypad base. It has several weaknesses, in which the data must be entered into the electronic log book by using a numeric code, the size of LCD display too small, and the size of the device is the relatively large. In 2012 to overcome the weaknesses from the past device, P3TKP has developed an electronic log book hardware with touch screen base. In 2013, P3TKP has made the improvement and development of electronic log book hardware, which changes the size of the touch screen becomes larger, the addition of the power bank as a backup battery power supply for electric power, the use of an internal GSM antenna, and changes in the process of downloading data from the device to the computer. From the hardware design process, it has produced a prototype of electronic log book. The device design process produces a new prototype of electronic log book and testing the device to determine success in the design of hardware. The testing consisted of testing the ARM and LCD touch screen, testing data transmission, battery life testing, and testing in the field (on fishing boat). The results of these tests include the fish catch data and the vessel tracking data can be viewed on the website, battery life for 13 hour, and the input data of which can be downloaded manually. From the test results, it is obtained
\end{abstract}

Pengembangan Perangkat Keras Elektronik Log Book Penangkapan Ikan Berbasis Layar Sentuh - Hadhi Nugroho dan

Agus Sufyan 
that the hardware has been successfully made to work well. This improvement is expected to provide convenience to the fishermen in the use of electronic log book which is expected to replace the use of the log book manually with paper.

Keywords: electronic log book, hardware, touch screen, ARM, battery

\section{PENDAHULUAN}

Penerapan log book penangkapan ikan di Indonesia diatur oleh Peraturan Menteri Kelautan dan Perikanan No. PER.18/MEN/2010 tentang Log Book Penangkapan Ikan. Peraturan Menteri tersebut menegaskan bahwa setiap kapal perikanan yang memiliki Surat Izin Penangkapan Ikan (SIPI) wajib mengisi log book yang diisi pada setiap operasi penangkapan ikan.

Namun pada kenyataannya, penggunaan log book secara manual menggunakan kertas selama ini ternyata banyak mengalami kendala bagi nelayan. Kendala-kendala tersebut antara lain adalah banyaknya data yang harus dituliskan pada kertas log book mengakibatkan tulisan menjadi kecil dan tidak mudah terbaca. Kasus lainnya, kertas yang mudah basah dan sobek serta masalah kerahasiaan lokasi penangkapan menyebabkan log book tidak diiisikan secara benar. Selain itu dirasakan penerapan log book masih belum memberikan manfaat langsung kepada nelayan, sehingga mereka tidak merasa memiliki kewajiban untuk melakukan pengisian hasil penangkapannnya pada form log book yang sudah ditetapkan (Marzuki, 2010).

Untuk mengatasi kendala dalam pengisian $\log$ book penangkapan ikan secara manual menggunakan kertas, Pusat Pengkajian dan Perekayasaan Teknologi Kelautan dan Perikanan (P3TKP) sejak 2011 telah mengembangkan teknologi elektronik log book penangkapan ikan, dengan komunikasi data menggunakan teknologi dan jaringan GPRS (General Packet Radio Service). Elektronik log book penangkapan ikan, yang kemudian cukup disebut elektronik log book merupakan perangkat keras yang memiliki fungsi input data tangkapan ikan secara elektronik dan dilengkapi dengan fungsi rekam jejak kapal (Marzuki dan Nugroho, 2013). Elektronik log book diharapkan dapat menggantikan pengisian log book secara manual dengan menggunakan kertas. Sebagai tahap awal, P3TKP pada 2011 telah mengembangkan perangkat keras elektronik log book berbasis keypad (Gambar 1).
Alat ini berukuran panjang $27 \mathrm{~cm}$ dan lebar 23 $\mathrm{cm}$. Bagian utama alat ini adalah LCD (Liquid Crystal Display) untuk menampilkan tulisan, keypad untuk melakukan input data, antena GPS (Global Positioning System), antena GSM/GPRS, adaptor, dan casing. Kedua antena tersebut (antena GPS dan antena GSM/GPRS) menggunakan antena eksternal, yang harus terhubung ke perangkat keras menggunakan kabel. Alat ini juga dilengkapi dengan sensor oseanografi berupa sensor suhu, yang dapat dipasang jika akan digunakan untuk mengukur suhu permukaan laut. Alat ini hanya mengenal angka saja, sehingga semua masukan yang diperlukan harus dikonversikan ke dalam bentuk angka terlebih dahulu. Sebagai contoh, data nama ikan harus dimasukkan dengan kode angka tertentu yang sudah ditetapkan.

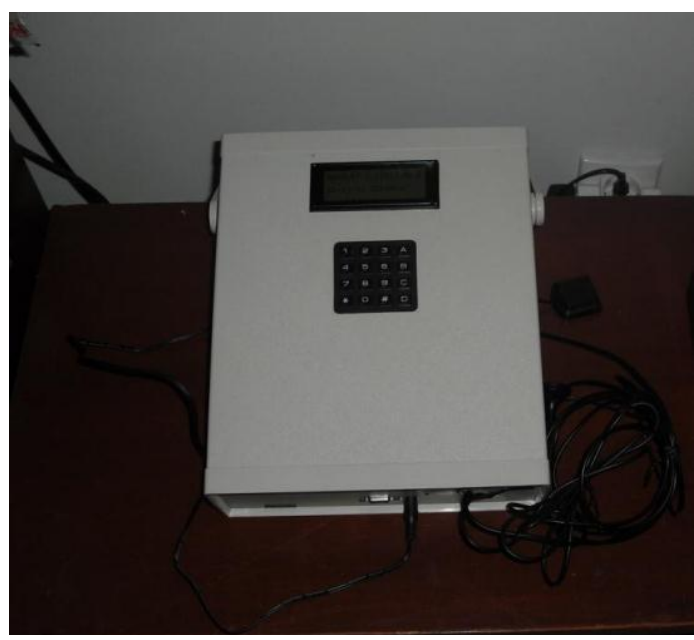

Gambar 1. Perangkat keras elektronik log book berbasis keypad

Figure 1. The hardware of keypad based electronic log book

Sumber: Dokumentasi pribadi

Prinsip kerja elektronik log book ini adalah sebagai berikut. Data penangkapan ikan, data posisi, data suhu, serta data lainnya yang masuk ke dalam alat akan langsung dikirim ke web server melalui jaringan GPRS (General Packet Radio Service). Jika tidak terdapat sinyal GPRS, maka data tersebut akan disimpan sementara di 
perekam data (data logger). Setelah menerima kembali sinyal GPRS, maka semua data yang tersimpan di perekam data akan terkirim secara otomatis ke web server.

Perangkat elektronik log book ini sudah berhasil memasukkan dan mengirimkan data penangkapan ikan secara elektronik. Namun, alat ini memiliki beberapa kelemahan. Semua data harus dimasukkan ke dalam alat dengan menggunakan kode angka, sehingga hal ini menjadi sulit dan tidak praktis, karena nelayan harus menghafal nama-nama ikan dengan kode angka. Selain itu, ukuran displai LCD juga kecil, sehingga tampilan hurufnya agak sulit dibaca oleh nelayan. Ukuran alat yang besar juga membuat alat ini agak berat dan tidak mudah untuk dibawa dengan tangan.

Untuk mengatasi masalah yang terjadi pada penggunaan perangkat keras elektronik log book berbasis keypad, maka P3TKP pada tahun 2012 telah mengembangkan perangkat keras elektronik $\log$ book berbasis layar sentuh. Hal yang perlu dipikirkan dalam penggunaan elektronik log book adalah bagaimana agar nelayan dapat memasukkan data ke dalam elektronik log book dengan upaya minimum tanpa mengganggu aktivitasnya di atas kapal (Kourti dan Kotsakis, 2007). Dengan menggunakan layar sentuh, tampilan akan lebih mudah dilihat dan dipahami (user friendly), sehingga tidak menimbulkan kesulitan bagi nelayan untuk melakukan pengisian data penangkapan ikan.

Dibanding dengan piranti masukan lainnya, layar sentuh dapat dikatakan sebagai piranti masukan yang paling sederhana, intuitif, dan mudah dipelajari. Antar muka layar sentuh memungkinkan pengguna untuk menjalankan sistem komputer dengan menyentuh simbol pada layar (Sofyan, 2001).

Sistem layar sentuh secara umum terdiri dari tiga komponen dasar, yaitu sensor sentuh, kontroler, dan software driver (Sofyan, 2001). Sensor layar sentuh adalah panel kaca transparan dengan permukaan yang responsif terhadap sentuhan. Menyentuh layar dapat menyebabkan perubahan tegangan atau sinyal. Perubahan ini digunakan untuk menentukan lokasi sentuhan pada layar. Kontroler berfungsi untuk memproses masukan dari sensor dan mengirimkan data yang terjadi ke komputer melalui antar muka serial atau bus.
Sedangkan software driver memungkinkan layar sentuh berinteraksi dengan sistem operasi komputer. Komponen-komponen pada sistem layar sentuh dapat dilihat pada Gambar 2.

Hasil pengembangan perangkat keras elektronik log book berbasis layar sentuh pada tahun 2012 dapat dilihat pada Gambar 3. Alat ini berukuran panjang $18 \mathrm{~cm}$, lebar $11 \mathrm{~cm}$, dan tebal $4 \mathrm{~cm}$, dengan layar sentuh berukuran 3,5 inch. Secara fisik, ukuran alat ini sudah lebih kecil dibanding dengan ukuran alat sebelumnya. Kelengkapan alat ini adalah antena GPS (Global Positioning System) untuk melacak posisi koordinat, antena GSM/GPRS untuk komunikasi data, serta adaptor. Kedua antena tersebut (antena GPS dan antena GSM/GPRS) masih menggunakan antena eksternal. Alat ini juga dilengkapi dengan sensor suhu sebagai sensor oseanografi.

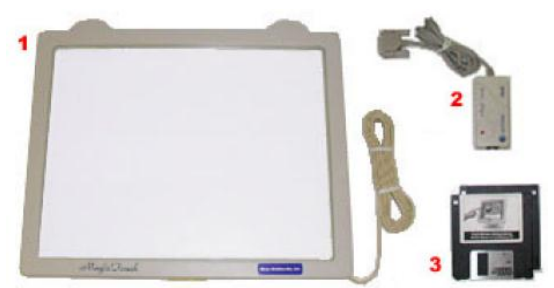

Gambar 2. Komponen-komponen pada sistem layar sentuh

Figure 2. Components of touch screen system Sumber: Willy (2013)

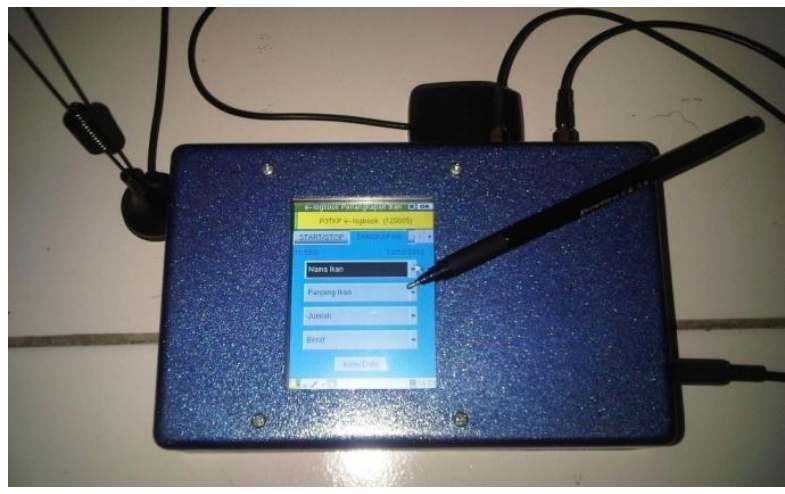

Gambar 3. Perangkat keras elektronik log book berbasis layar sentuh tahun 2012

Figure 3. The hardware of touch screen based electronic log book years 2012 Sumber: Dokumentasi pribadi

Alat ini bekerja dalam arus dan tegangan searah (DC). Oleh karena itu, untuk menyalakan alat, alat harus dihubungkan dengan adaptor yang berfungsi 
sebagai penyearah sebelum dihubungkan ke sumber listrik bolak-balik (AC). Setelah alat menyala, akan terjadi proses booting terminal yang berlangsung selama 1-2 menit dan proses loading selama 3-4 menit. Setelah proses loading, maka alat otomatis akan langsung masuk ke menu aplikasi dan siap digunakan. Jika kabel adaptor dicabut, maka alat akan langsung mati. Saat operasional di kapal, sejak kapal berangkat dari pelabuhan, melakukan operasi penangkapan ikan, dan kembali lagi ke pelabuhan, perangkat keras elektronik log book harus selalu menyala. Sebab, alat ini juga dilengkapi dengan fitur rekam jejak kapal. Dengan fitur ini, elektronik $\log$ book diprogram untuk mengirimkan data posisi koordinat setiap periode tertentu secara otomatis, sehingga pergerakan kapal dapat dipantau (Marzuki dan Nugroho, 2013). Oleh karena itu, untuk operasional di kapal, alat harus selalu terhubung ke sumber listrik.

Elektronik $\log$ book berbasis layar sentuh ini memiliki beberapa kelebihan dibanding dengan elektronik $\log$ book berbasis keypad, yaitu tampilan lebih mudah dilihat dan dipahami (user friendly) serta tidak perlu menggunakan kode angka untuk melakukan input data tangkapan ikan (Marzuki dan Nugroho, 2013). Selain itu, ukuran alat yang lebih kecil menjadikan alat ini lebih praktis dan mudah dibawa untuk operasional di atas kapal.

Meskipun begitu, setelah dilakukan uji coba pada nelayan di atas kapal, ada beberapa kelemahan pada alat ini. Ukuran layar sentuh yang kecil menyebabkan tulisan yang terbaca juga kecil. Alat yang harus selalu terhubung ke sumber listrik juga menimbulkan persoalan, karena suplai listrik di kapal saat beroperasi di tengah laut tidak selalu tersedia selama 24 jam dengan alasan penghematan bahan bakar. Selain itu, kabel antena GSM/GPRS yang terlalu panjang juga merepotkan nelayan dalam mengoperasikan alat. Selain itu, setelah mendapat masukan dari pihak Ditjen Perikanan Tangkap - Kementerian Kelautan dan Perikanan selaku penyelenggara sistem log book penangkapan ikan di Indonesia, sistem penyimpanan data pada alat elektronik $\log$ book juga harus diubah. Semua data pada elektronik log book selama operasi penangkapan ikan selain harus terkirim ke web server, juga harus tetap tersimpan di perekam data dan dapat diunduh oleh pihak pelabuhan perikanan saat kapal mendarat kembali di pelabuhan.

Untuk itu, di tahun 2013 dilakukan pengembangan perangkat keras elektronik log book. Pengembangan tersebut adalah perubahan ukuran layar sentuh menjadi lebih besar, penambahan pengisi baterai portabel (power bank) sebagai baterai cadangan untuk suplai daya listrik alat, penggunaan antena GSM internal, serta perubahan sistem penyimpanan data di mana data elektronik log book dapat diunduh ke dalam komputer melalui antarmuka USB (Universal Serial Bus). Pembatasan masalah pada tulisan ini hanya membahas tentang perangkat keras alat yang dibuat, tidak membahas perangkat lunak tampilan aplikasi pada elektronik log book.

\section{BAHAN DAN METODE}

\subsection{Bahan yang Digunakan}

Bahan-bahan/komponen untuk membuat perangkat keras elektronik log book adalah sebagai berikut:

\section{FriendlyARM Mini2440}

ARM adalah sebuah single board computer berbasis mikroprosesor. Desain yang sederhana membuat prosesor ARM cocok untuk aplikasi berdaya rendah. Hal ini membuat prosesor ARM mendominasi pasar mobile electronic dan embedded system di mana membutuhkan daya dan harga yang rendah (Anonim, 2014). Pada penelitian ini digunakan ARM dengan merk dan tipe FriendlyARM $^{\circledR}$ Mini2440. ARM tersebut berukuran $10 \times 10 \mathrm{~cm}$, serta menggunakan mikroprosesor Samsung S3C2440 ARM9 (Guangzhou FriendlyARM Computer Tech Co., Ltd. 2013). Bagian utama dari ARM tersebut adalah CPU, LCD layar sentuh, perangkat antar muka, power supply, dan sistem operasi. Layar sentuh yang digunakan berukuran 7 inch. (Gambar 4)

2. Sensor suhu DS1820

Sensor suhu merupakan suatu komponen elektronika yang dapat menangkap perubahan temperatur lingkungan lalu mengkonversinya menjadi besaran listrik. Pada penelitian ini, sensor suhu yang digunakan adalah DS1820. 
DS18B20 (Gambar 5) adalah sensor suhu yang menyediakan 9 bit untuk pengukuran suhu dalam derajat celcius. Komunikasi sensor ini melaluli I-wire bus yang berarti hanya membutuhkan satu jalur data untuk berkomunikasi dengan mikrokontroler. Sensor ini beroperasi untuk rentang temperatur $-55^{\circ} \mathrm{C}$ hingga $125^{\circ} \mathrm{C}$ dan memiliki keakurasian \pm $0,5^{\circ} \mathrm{C}$ (Dallas Semiconductor, 2013). Sensor suhu DS1820 terdiri dari 3 pin. Pin GND terhubung ke pentanahan (grounding), pin DQ sebagai input/ouput data, dan pin VDD terhubung ke catu daya $5 \mathrm{~V}$.

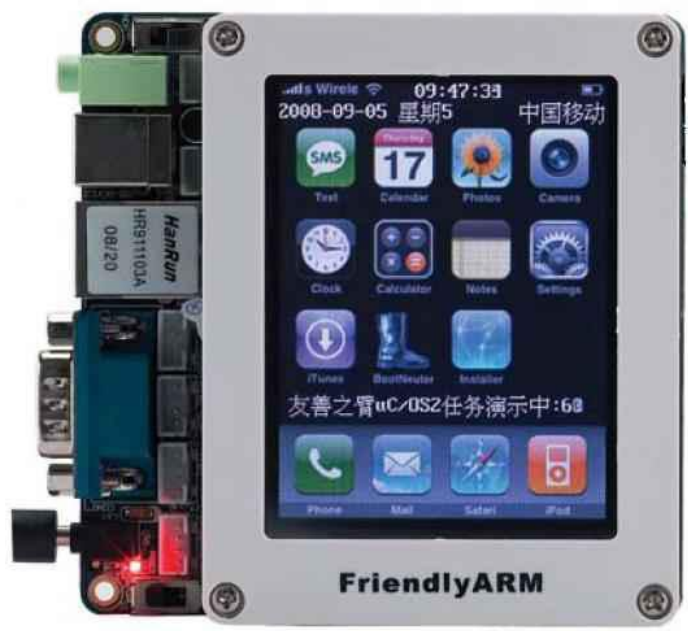

Gambar 4. FriendlyARM ${ }^{\circledR}$ Mini2440

Figure 4. FriendlyARM ${ }^{\circledR}$ Mini2440

Sumber: Guangzhou FriendlyARM Computer Tech Co. Ltd. (2013)

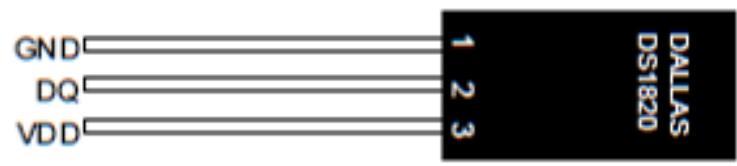

Gambar 5. Sensor suhu DS1820

Figure 5. Temperature sensor DS1820

Sumber: Dallas Semiconductor (2013)

3. Mikrokontroler AVR ATmega8

Mikrokontroler AVR merupakan seri mikrokontroler CMOS 8-bit buatan Atmel berbasis arsitektur RISC (Reduced Instruction Set Computer). Hampir semua instruksi dieksekusi dalam satu siklus clock. AVR tidak perlu menggunakan osilator eksternal karena di dalamnya sudah terdapat osilator internal. Selain itu, kelebihan AVR adalah memiliki Power-On Reset, yaitu tidak perlu ada tombol reset dari luar karena cukup hanya dengan mematikan supply, maka secara otomatis AVR akan melakukan reset (Hadi, 2008).

ATmega8 merupakan salah satu seri mikrokontroler AVR. Mikrokontroler ini mampu mengeksekusi instruksi dengan kecepatan maksimum 16 MIPS pada frekuensi $16 \mathrm{MHz}$. Mikrokontroler ini bekerja pada tegangan antara 4,5 $-5,5 \mathrm{~V}$ (Atmel Corporation, 2003).

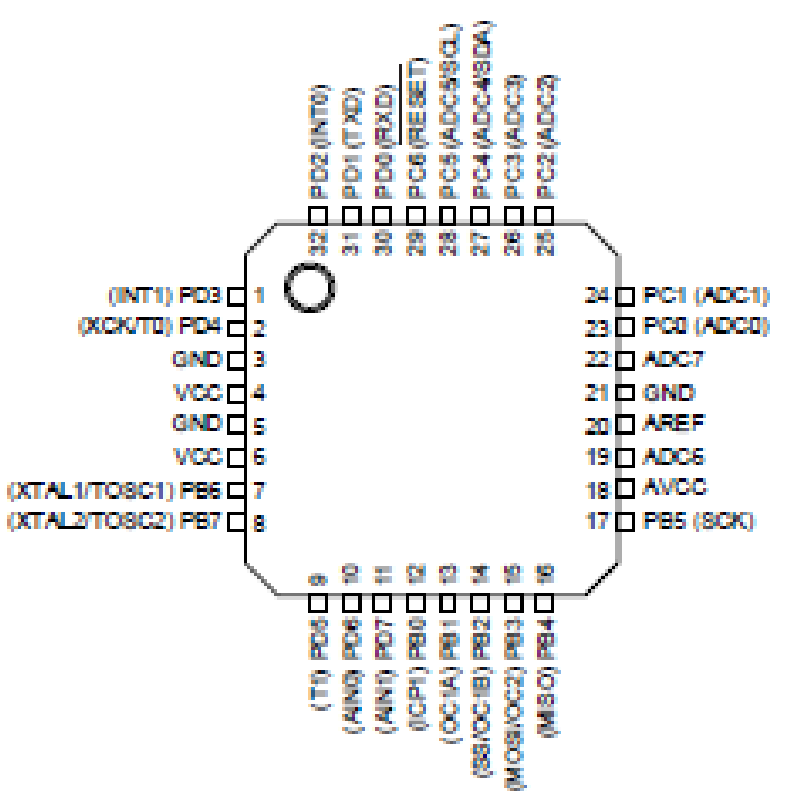

Gambar 6. Konfigurasi pin mikrokontroler ATmega8

Figure 6. ATmega8 microcontroller pin configuration

Sumber: Atmel Corporation (2003)

Mikrokontroler AVR ATmega8 memiliki 32 pin. Fungsi beberapa di antaranya adalah: pin 4 (VCC) untuk suplai tegangan digital; pin 3, 5,21 untuk pentanahan (ground). Mikrokontroler AVR ATmega8 pada perangkat keras elektronik log book ini berfungsi untuk membaca data suhu dari sensor suhu, lalu mengirim data suhu tersebut ke ARM untuk diproses dan ditampilkan di LCD layar sentuh. 
4. Modul GSM/GPRS dan GPS

Modul GSM/GPRS digunakan untuk komunikasi data menggunakan jaringan GSM/GPRS, sedangkan modul GPS digunakan untuk melihat posisi koordinat lintang dan bujur. Kedua fungsi tersebut digabungkan ke dalam satu modul. Modul yang digunakan adalah SIM908 yang diproduksi oleh Shanghai SIMCom Wireless Solutions. Modul ini berbentuk chip IC (integrated circuit) berukuran $30 \times 30$ × 3,2 $\mathrm{mm}$.
SIM908 memiliki 80 pin. Fungsi beberapa di antaranya adalah: pin 62-63 untuk power supply; pin 6-9 untuk antarmuka LCD; pin 31-36 untuk antar muka keypad; pin 15-16 untuk antarmuka GPS/debug; pin 17-20 untuk antarmuka SIM card; pin 59 untuk antarmuka antena GSM; pin 79 untuk antar muka antena GPS. Di bagian atas modul ini, terdapat SIM card holder sebagai tempat untuk memasang SIM card untuk melakukan komunikasi data selular (Shanghai SIMCom Wireless Solutions, 2011).

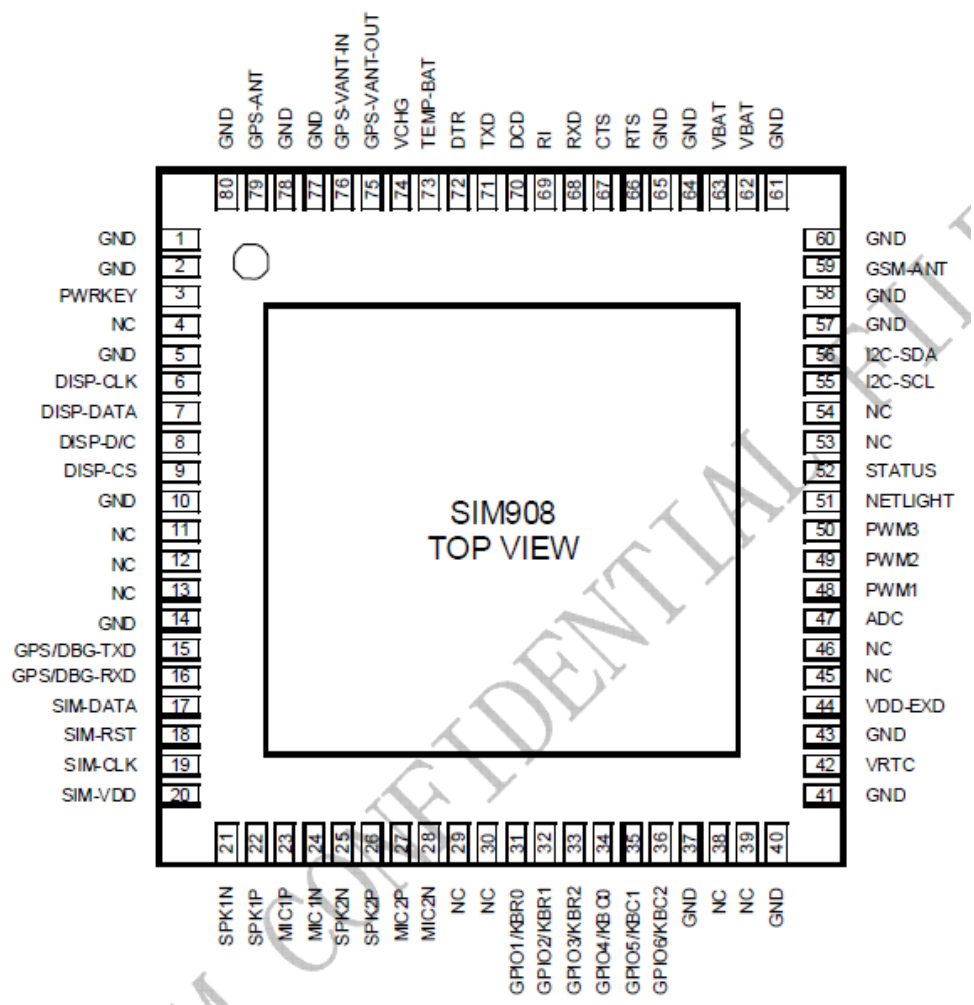

Gambar 7. Konfigurasi pin SIM908

Figure 7. SIM908 pin configuration

Sumber: Shanghai SIMCom Wireless Solutions (2011)

5. Kartu SIM

Kartu SIM (Subscriber Identity Module) adalah sebuah chip memori portabel yang digunakan dalam beberapa model telepon seluler (Syariman, 2012). Kartu SIM ini berfungsi sebagai nomor identitas perangkat bagi operator jaringan seluler.

6. Pengisi baterai portabel (power bank)

Pengisi baterai portabel, atau yang lebih dikenal dengan nama power bank adalah sebuah alat yang digunakan untuk memasukkan energi listrik ke dalam baterai yang bisa diisi ulang tanpa harus menghubungkan alat tersebut pada outlet listrik. Pengisi baterai ini disebut portabel karena berbeda dengan pengisi baterai yang harus dihubungkan pada outlet listrik, pengisi portabel dapat digunakan tanpa harus menghubungkan pada perangkat listrik. Pengisi baterai portabel ini memiliki daya tampung energi listrik sehingga ketika daya tersebut telah habis terpakai, energi listrik harus kembali diisi kembali dengan cara menghubungkan kabel dengan outlet lisrtik (Anonim, 2014). 
Pengisi baterai portabel yang digunakan adalah merk Sturdy, dengan kapasitas 15000 $\mathrm{mAh}$. Baterai yang digunakan adalah baterai Lithium Ion (Li-ion). Tegangan dan arus masukan sebesar $5 \mathrm{~V}-1 \mathrm{~A}$, sedangkan keluaran sebesar $5 \mathrm{~V}-1,5 \mathrm{~A}$ dan $5 \mathrm{~V}-2 \mathrm{~A}$ (dual output). Lama pengisian baterai 14-16 jam. Memiliki ukuran 123 x 77 x 23 mm.

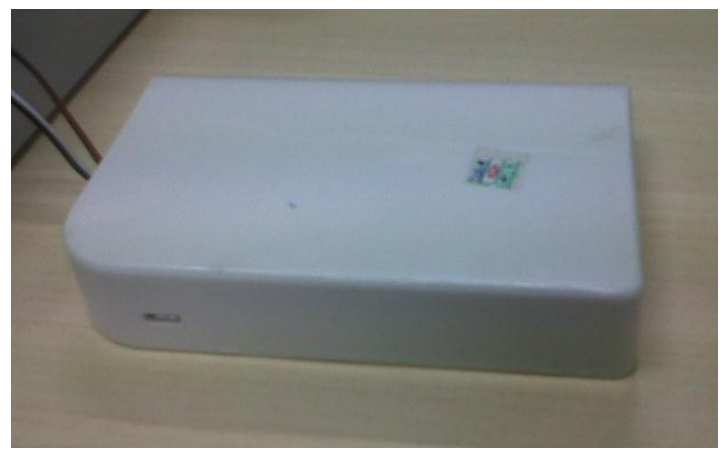

Gambar 8. Power bank merk Sturdy kapasitas $15000 \mathrm{mAh}$

Figure 8. Sturdy power bank with capacity $15000 \mathrm{mAh}$

Sumber: Dokumentasi pribadi

\section{Adaptor}

Adaptor adalah alat yang digunakan untuk mengubah tegangan bolak-balik (AC) menjadi tegangan searah (DC). Komponen utama di dalam sebuah adaptor adalah transformator step down dan dioda. Transformator step down berfungsi untuk menurunkan tegangan listrik, sedangkan dioda berfungsi untuk menyearahkan tegangan listrik yang dihasilkan transformator step down tersebut. Adaptor yang digunakan memiliki input 100$240 \mathrm{~V}$ dan $0,8 \mathrm{~A}$, serta output $5 \mathrm{~V}$ dan $4,9 \mathrm{~A}$.

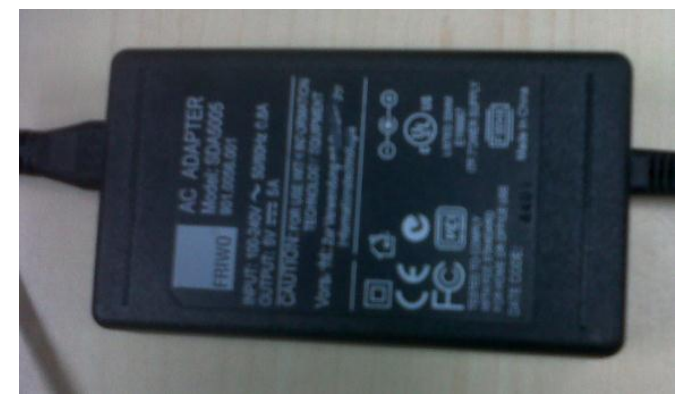

Gambar 9. Adaptor

Figure 9. Adaptor

Sumber: Dokumentasi pribadi
8. Antena GSM/GPRS

Antena GSM/GPRS berfungsi untuk memancarkan dan menerima data ke jaringan GSM/GPRS melalui udara. Antena yang digunakan menggunakan antena internal, yaitu antena yang dipasang di dalam perangkat keras. Kelebihannya adalah tidak memerlukan kabel yang panjang sehingga memudahkan dalam penggunaan/ pengoperasian perangkat keras.

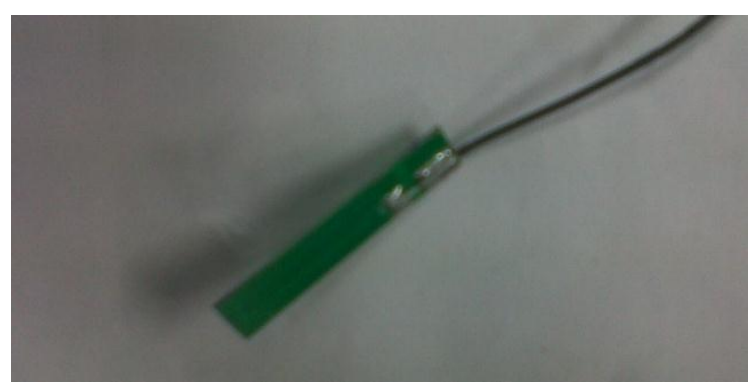

Gambar 10. Antena GSM/GPRS

Figure 10. (GSM/GPRS antenna)

Sumber: Dokumentasi pribadi

\section{Antena GPS}

GPS (Global Positioning System) merupakan sistem untuk menentukan posisi dan navigasi secara global dengan menggunakan satelit (Abidin, 1995). Antena GPS berfungsi sebagai sensor untuk mencari koordinat di mana elektronik log book berada. Koordinat ini diukur dalam lintang dan bujur. Antena GPS yang digunakan adalah merk ROHS, memiliki frekuensi $1575,42 \mathrm{MHz}$ dan tegangan 3-5 V.
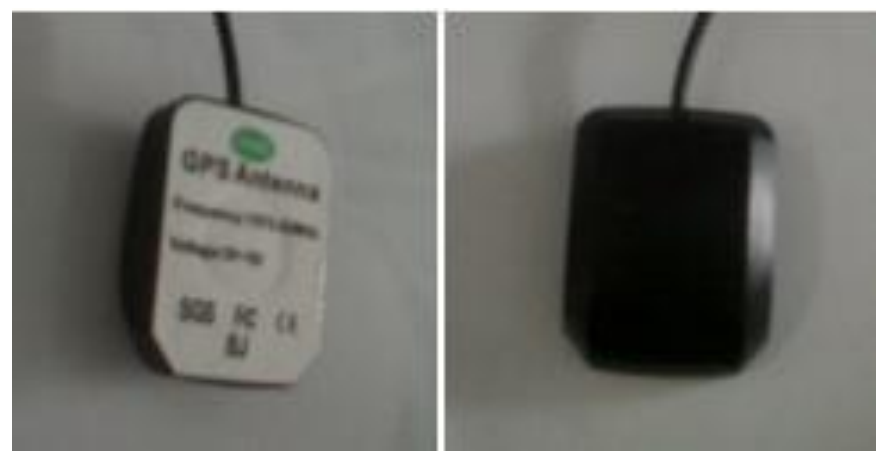

Gambar 11. Antena GPS

Figure 11. GPS antenna

Sumber: Dokumentasi pribadi 
10. Kotak casing

Kotak casing digunakan untuk meletakkan semua komponen yang digunakan dalam merancang perangkat keras elektronik log book. Kotak casing tersebut terbuat dari bahan plastik. Berukuran panjang $23 \mathrm{~cm}$, lebar 15 $\mathrm{cm}$, dan tebal $7 \mathrm{~cm}$.

\subsection{Perancangan Perangkat Keras}

Semua komponen untuk membuat perangkat keras elektronik log book ini kemudian dirancang. Diagram blok rangkaian perangkat keras elektronik log book dapat dilihat pada Gambar 12.

Rangkaian komponen tersebut kemudian diatur dan dipasang pada kotak pembungkus (casing box). Tata letak komponen-komponen tersebut pada kotak pembungkus dapat dilihat pada Gambar 13 dan Gambar 14.

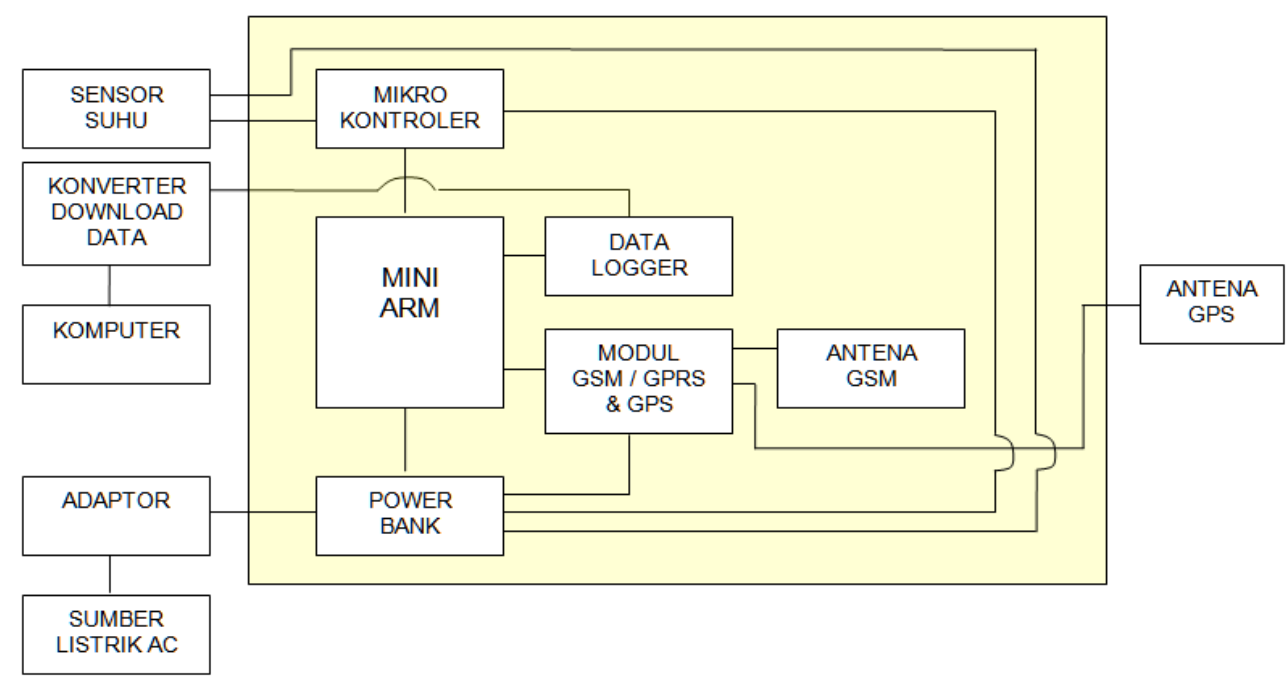

Gambar 12. Diagram blok rangkaian perangkat keras elektronik log book Figure 12. Block diagram of electronic log book hardware circuit Sumber: Dokumentasi pribadi

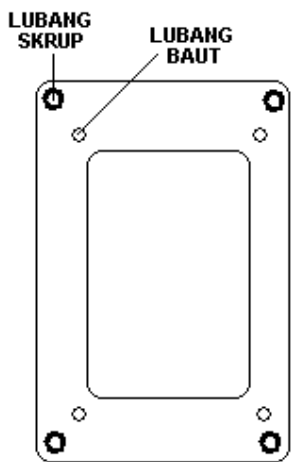

TUTUP BOX

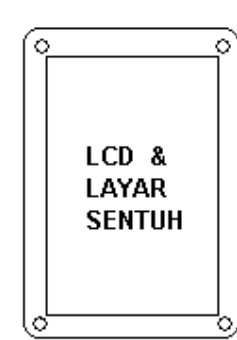

MODUL DISPLAI (DITEMPATKAN DI BAWAH TUTUP BOX)
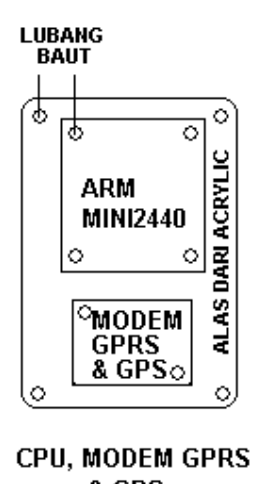

\& GPS

(DITEMPATKAN DI BAWAH MODUL DISPLAI

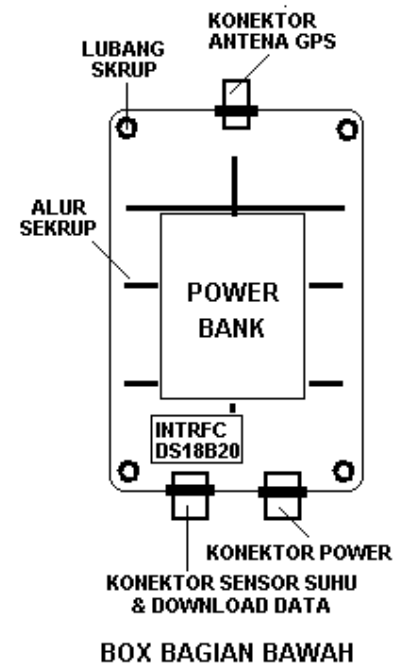

Gambar 13. Tata letak komponen pada kotak pembungkus (tampak atas)

Figure 13. Lay out of components at casing box (above view) Sumber: Dokumentasi pribadi 


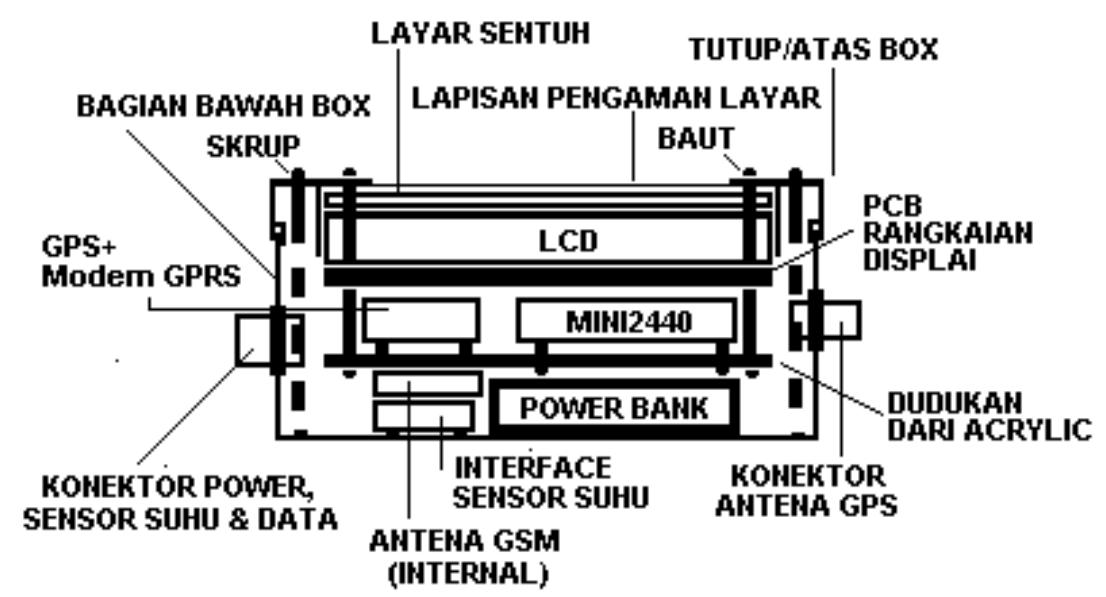

Gambar 14. Tata letak komponen pada kotak pembungkus (tampak samping) Figure 14. Lay out of components at casing box (side view) Sumber: Dokumentasi pribadi

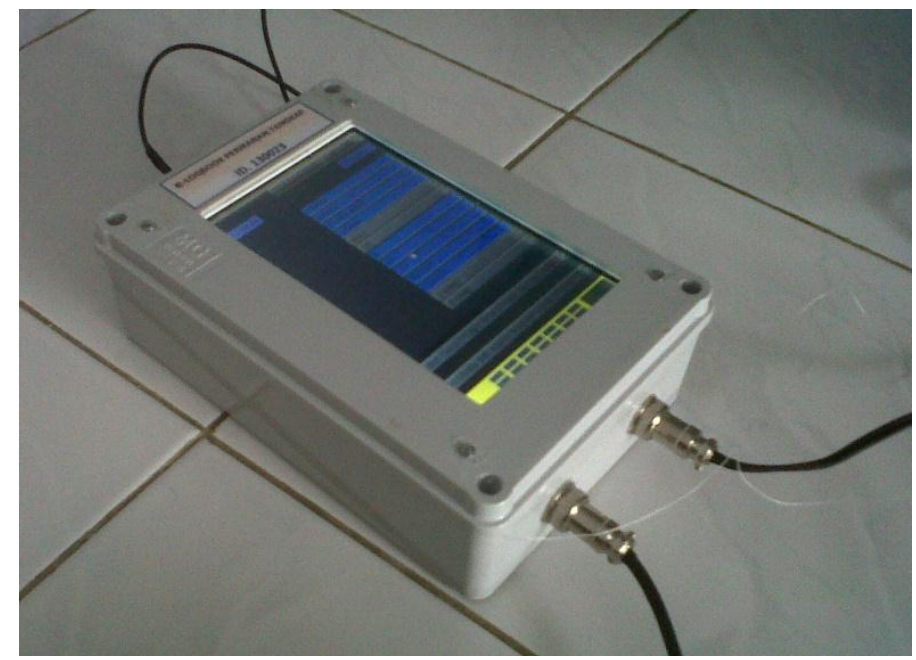

Gambar 15. Perangkat keras elektronik log book berbasis layar sentuh tahun 2013

Figure 15. The hardware of electronic log book touchscreen based year 2013 Sumber: Dokumentasi pribadi

\subsection{Pengujian Perangkat Keras}

Pengujian dilakukan untuk mengetahui keberhasilan dalam perancangan perangkat keras. Pengujian tersebut terdiri dari pengujian ARM dan LCD layar sentuh, pengujian pengiriman data, pengujian daya tahan baterai, serta pengujian di lapangan (di atas kapal nelayan).
Alat ini berukuran panjang $23 \mathrm{~cm}$, lebar $15 \mathrm{~cm}$, dan tebal $7 \mathrm{~cm}$, dengan layar sentuh berukuran 7 inch. Ukuran alat lebih besar dari perangkat keras tahun 2012, karena ukuran layar sentuh lebih besar 2 kali dan ada tambahan ruang untuk tempat power bank. Tetapi ukuran ini masih lebih kecil dibanding dengan perangkat keras tahun 2011.

Jadi alat masih praktis dan mudah dibawa untuk operasional di atas kapal. Antarmuka yang ada pada alat ini adalah kabel power dan adaptor 5V/4,9A, sensor suhu, dan antena GPS.

Dari perancangan dan perakitan, dihasilkan perangkat keras elektronik log book seperti Gambar 15. 


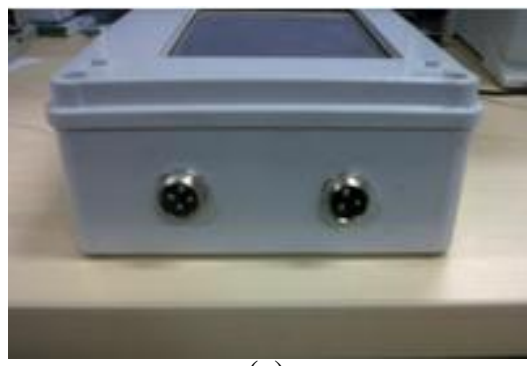

(a)

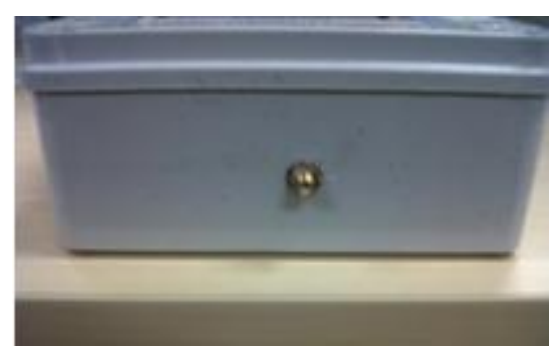

(b)

Gambar 16. Antarmuka elektronik log book

a. Sensor suhu dan kabel power, b. Antena GPS

Figure 16. Interface of electronic log book

a. Temperature sensor and power cable, $b$. GPS antenna

Sumber: Dokumentasi pribadi
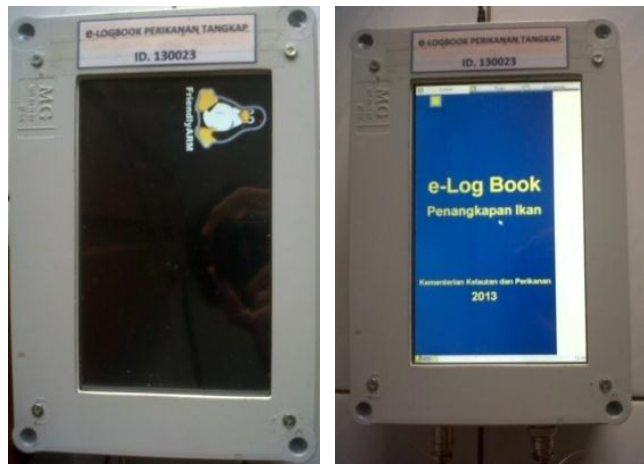

Gambar 17. Proses booting dan loading alat

Figure 17. Booting and loading process of device Sumber: Dokumentasi pribadi

Pengujian perangkat keras dilakukan dengan menyalakan alat terlebih dahulu. Sensor suhu dan antena GPS dipasang, kemudian alat diberi catu daya 5 volt yang dihasilkan melalui adaptor $220 \mathrm{~V}$. Alat akan melakukan proses booting selama 20 detik dan proses loading selama 4 menit.

Setelah proses loading selesai, maka alat otomatis akan langsung masuk ke menu aplikasi, yang dapat dilihat pada Gambar 18.

Gambar 18 merupakan tampilan menu aplikasi yang tampil pada layar sentuh elektronik log book setelah alat selesai melakukan proses loading. Menu aplikasi yang ada pada elektronik log book adalah:

1. Data Kapal, berfungsi untuk input data kapal, data alat tangkap, data daerah penangkapan, serta data pelabuhan keberangkatan dan pendaratan.

2. Seting Alat, berfungsi untuk input data waktu dan aktivitas penangkapan ikan.
3. Tangkapan, berfungsi untuk input data hasil tangkapan.

4. Catatan, berfungsi untuk input catatan nakhoda/kapten kapal.

5. GPS, berfungsi untuk melihat posisi koordinat, arah (heading) kapal, laju kapal, dan kekuatan sinyal GPRS.

6. Info Cuaca, berfungsi untuk meminta informasi cuaca.

7. PPDPI, berfungsi untuk meminta informasi koordinat peta prakiraan daerah penangkapan ikan.

8. Harga Ikan, berfungsi untuk meminta informasi harga ikan.

9. Suhu, berfungsi untuk melihat dan mengirimkan data suhu dari sensor suhu.

10. Emergensi, berfungsi untuk mengirim data kondisi darurat di atas kapal.

11. SMS Info, berfungsi untuk melihat SMS yang masuk.

12. SMS Request, berfungsi untuk mengirim SMS ke nomor server. 
13. SIM Card, berfungsi untuk mengecek nomor kartu SIM dan sisa pulsa yang tersedia.

14. Konfigurasi, berfungsi untuk mengubah data kapal.

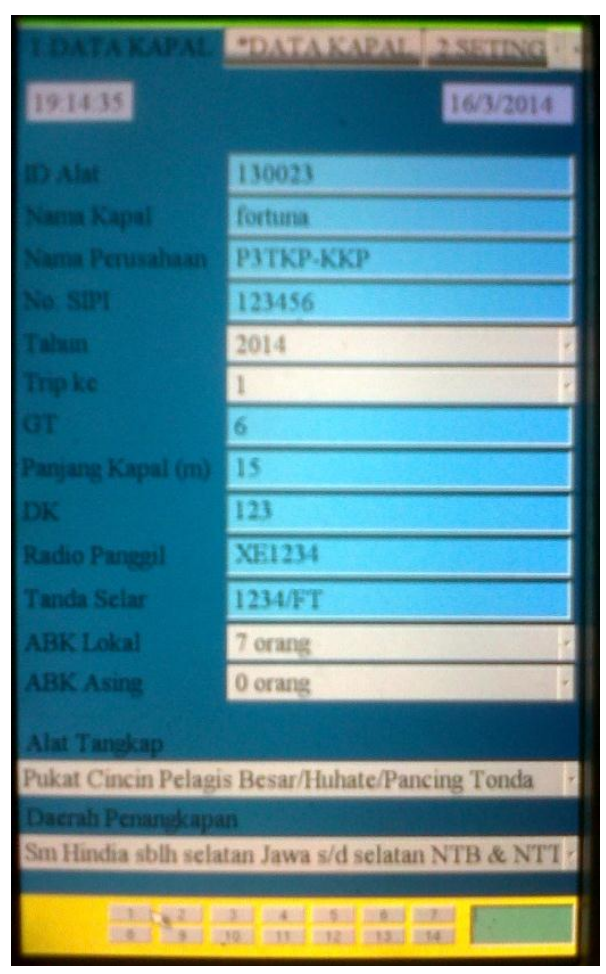

Gambar 18. Tampilan menu aplikasi elektronik log book setelah proses loading

Figure 18. Display of application menu at electronic log book after loading process

Sumber: Dokumentasi pribadi

Setelah proses loading alat selesai dan alat siap untuk dioperasikan, dilakukan pengujian pengiriman data. Sebagai contoh, dilakukan pengiriman data hasil tangkapan ikan pada menu "Tangkapan". Alat siap untuk melakukan proses penyimpanan dan pengiriman data jika indikator pada bagian atas layar sentuh menunjukkan warna hijau berkedip-kedip. Hal ini bisa dilihat pada Gambar 19.

Jika tombol "KIRIM DATA" pada menu tersebut disentuh, maka data hasil tangkapan ikan tersebut akan tersimpan di perekam data dan terkirim ke web server jika terdapat sinyal GPRS. Jika tidak terdapat sinyal GPRS, maka data tersebut akan tersimpan di perekam data dan akan terkirim ke web server setelah mendapat sinyal GPRS.

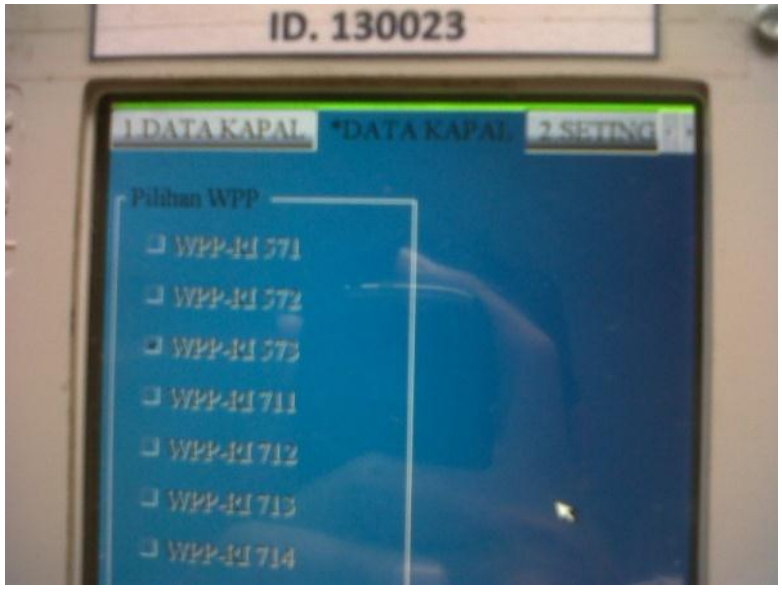

Gambar 19. Indikasi warna hijau pada layar sentuh menunjukkan alat siap untuk menyimpan dan mengirim data

Figure 19. Green indicator at touch screen showing the device is ready to storing and sending data Sumber: Dokumentasi pribadi

Setelah tombol "KIRIM DATA" tersebut, maka indikator pada bagian atas layar sentuh menunjukkan warna merah berkedip-kedip. Hal ini dapat dilihat pada Gambar 20.

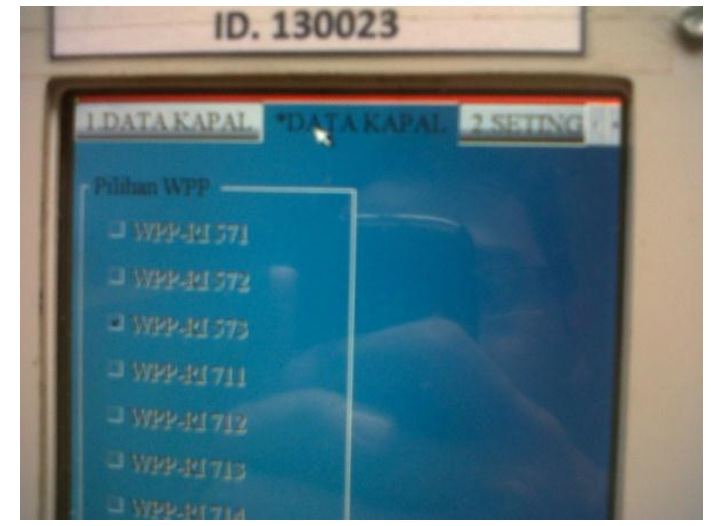

Gambar 20. Indikasi warna merah pada layar sentuh menunjukkan sedang ada proses penyimpanan dan pengiriman data

Figure 20. Red indicator at touch screen showing that being there is the process of storing and sending data Sumber: Dokumentasi pribadi

Indikasi warna merah tersebut menunjukkan bahwa sedang ada proses penyimpanan dan pengiriman data pada alat. Proses ini berlangsung sekitar 1-2 menit. Jika saat indikator pada layar sentuh masih berwarna merah dan dilakukan pengiriman data lainnya, maka akan muncul pesan seperti pada Gambar 21. 


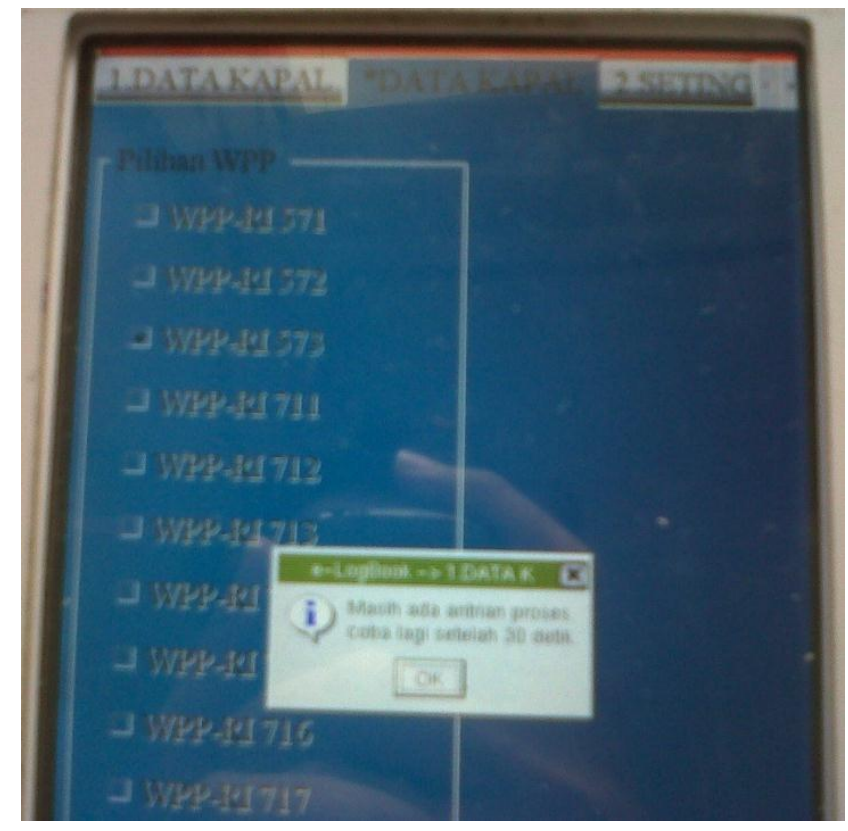

Gambar 21. Pesan yang muncul pada saat indikator masih berwarna merah

Figure 21. Messages that appear when the indicator is still red

Sumber: Dokumentasi pribadi

Setelah proses penyimpanan dan pengiriman data selesai dilakukan, maka indikator pada layar sentuh akan kembali berwarna hijau berkedipkedip.
Kemudian, untuk melihat data yang dikirim dari alat ke web server, dapat dilakukan dengan membuka alamat situs http://167.205.110.252/elogbook. Berikut adalah contoh tampilan di internet untuk data hasil penangkapan ikan.

Gambar 22 menunjukkan tampilan data hasil penangkapan ikan di web. Data nama ikan, jumlah ikan, dan berat tangkapan merupakan data yang berasal dari pengisian pada elektronik log book. Sedangkan data tanggal, waktu, ID device, lintang (latitude), dan bujur (longitude) merupakan data yang terkirim secara otomatis pada saat melakukan pengisian data hasil penangkapan ikan. ID device merupakan nomor identitas dari alat elektronik log book yang mewakili identitas kapal.

Dari data seperti yang terlihat pada Gambar 22, dapat disimpulkan bahwa dengan menggunakan antena GSM internal, data dari elektronik log book tetap dapat terkirim ke web server.

Alat ini juga dilengkapi dengan fitur rekam jejak kapal (vessel tracking). Dengan fitur ini, alat diatur agar dapat mengirim posisi koordinat setiap 30 menit sekali secara otomatis. Untuk pengujian, dilakukan pemasangan elektronik log book di atas kapal dan dilakukan pengujian di tengah laut (Gambar 23).

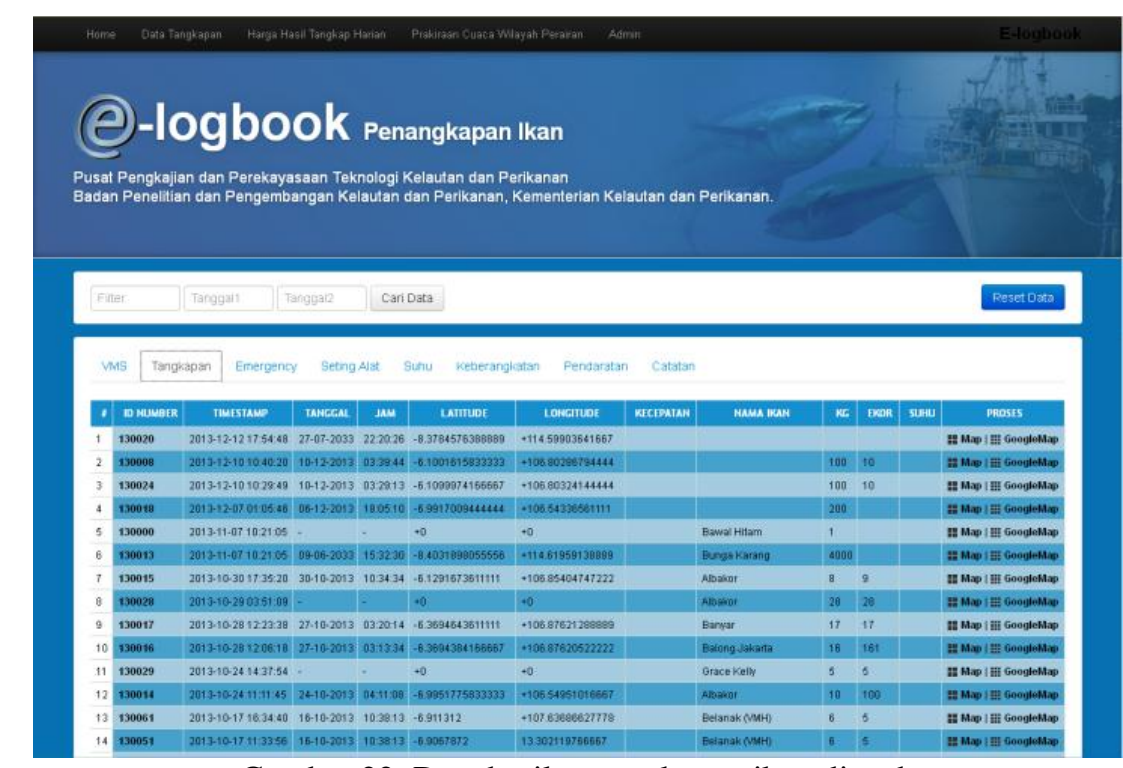

Gambar 22. Data hasil penangkapan ikan di web

Figure 22. Catch data in the web

Sumber: Dokumentasi pribadi 


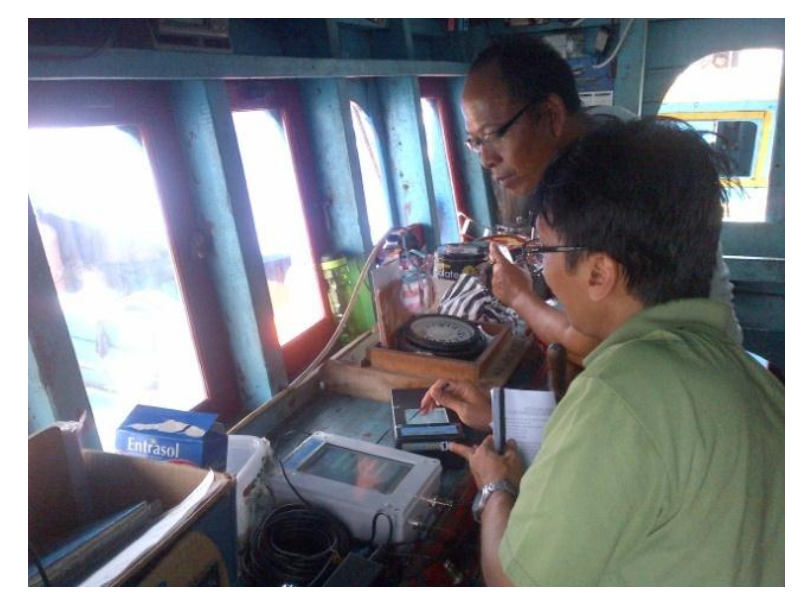

Gambar 23. Pengujian pemasangan elektronik log book di atas kapal

Figure 23. The trial of installation an electronic log book on vessel

Sumber: Dokumentasi pribadi

Hasil pengujian fitur rekam jejak kapal dapat dilihat pada Gambar 24.

Dari hasil pengujian tersebut, terlihat bahwa alat berhasil mengirim data rekam jejak kapal setiap 30 menit sekali. Jika data koordinat tersebut diplotkan di google map, hasilnya dapat dilihat pada Gambar 25.
Untuk pengujian daya tahan baterai, dilakukan dengan mengisi baterai alat sampai penuh. Setelah baterai penuh, kabel power dicabut, kemudian alat didiamkan tanpa dilakukan proses pengiriman data apapun, kecuali pengiriman data rekam jejak kapal setiap 30 menit. Dari pengujian tersebut, diperoleh hasil bahwa daya tahan baterai sekitar 13 jam.

Semua data yang tersimpan pada perekam data (data logger) elektronik log book dapat diunduh ke komputer. Untuk mengunduh data tersebut, elektronik log book harus dalam keadaan menyala. Komputer yang akan digunakan juga harus diinstal program untuk mengunduh data tersebut. Elektronik $\log$ book kemudian dihubungkan ke komputer menggunakan konverter (Gambar 26).

Salah satu kabel konektor pada konverter tersebut dihubungkan ke elektronik log book melalui antarmuka sensor suhu, sedangkan kabel konektor lainnya dihubungkan ke komputer melalui antarmuka USB. Pada komputer, program untuk mengunduh data elektronik log book dijalankan. Tampilan program tersebut dapat dilihat pada Gambar 27.

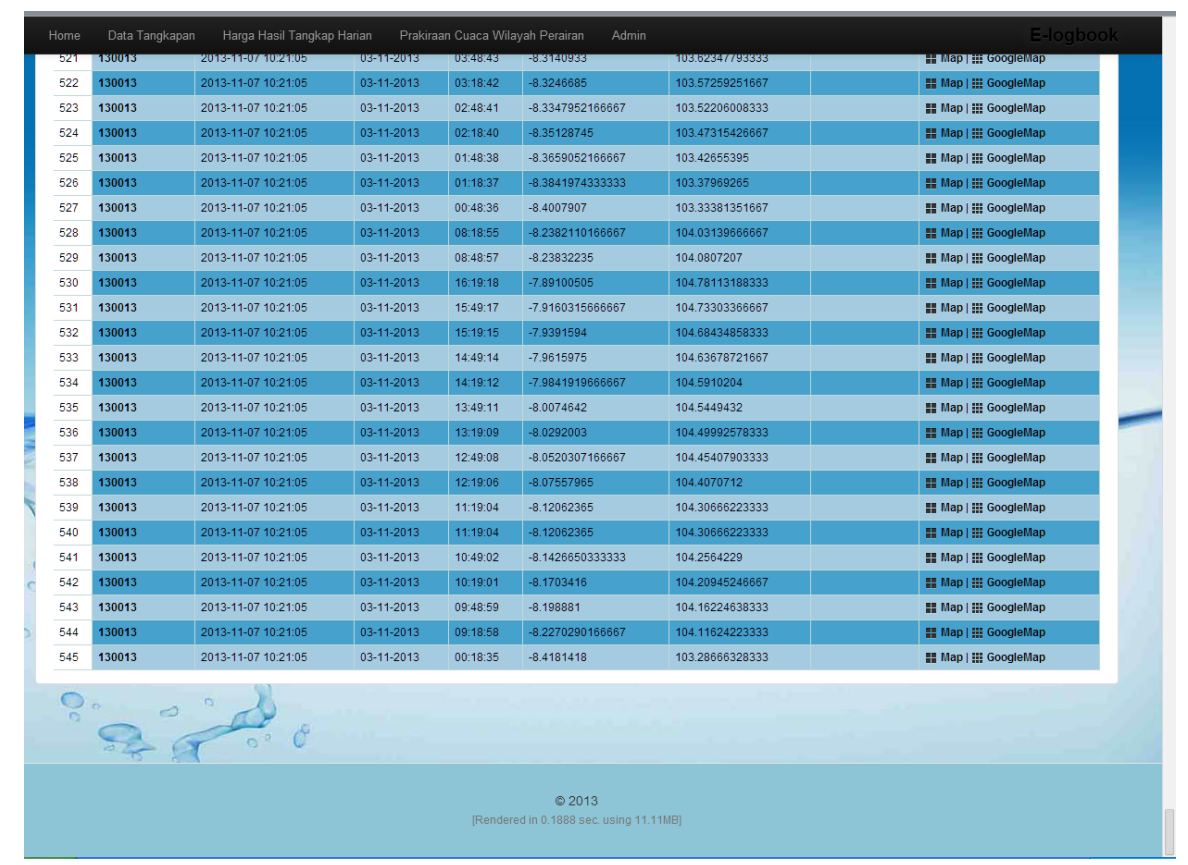

Gambar 24. Hasil pengujian fitur rekam jejak kapal di web

Figure 24. Trial result of vessel tracking in the web Sumber: Dokumentasi pribadi 


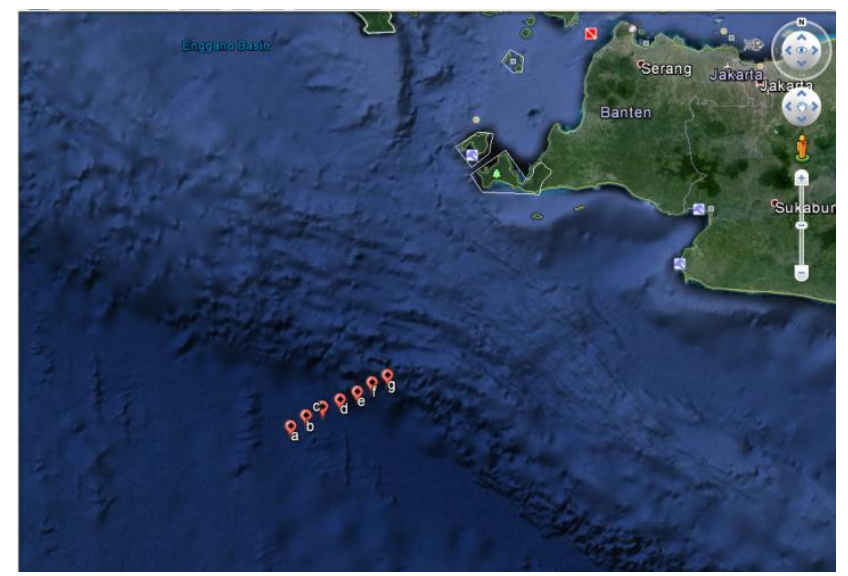

Gambar 25. Tampilan data rekam jejak kapal selama uji coba elektronik log book dilihat dengan Googlemap Figure 25. Display of vessel tracking data during the trial of electronic log book seen with Googlemap Sumber: Googlemap

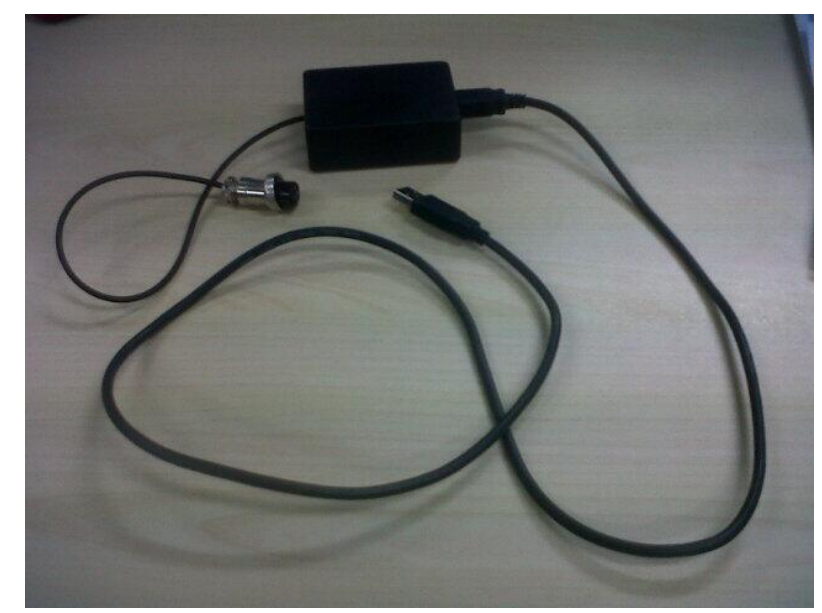

Gambar 26. Konverter untuk mengunduh data elektronik log book ke dalam komputer Figure 26. Converter to download the data of electronic log book to the computer Sumber: Dokumentasi pribadi

Setelah program di komputer di-set (siap untuk menerima data), maka pengiriman data dari elektronik log book dapat dilakukan dengan cara memasukkan password kemudian menekan tombol "Download Data" yang ada di menu "Konfigurasi" pada elektronik log book (Gambar 28).

File yang diunduh kemudian dapat disimpan di komputer. Format data tersebut pada komputer adalah .txt. Contoh data yang diunduh dari elektronik $\log$ book dapat dilihat pada Gambar 29.

Dari pengujian yang sudah dilakukan tersebut, telah berhasil dilakukan pengembangan perangkat keras elektronik log book penangkapan ikan berbasis layar sentuh. Pengembangan ini diharapkan mampu memberikan kemudahan kepada nelayan dalam menggunakan elektronik $\log$ book sehingga diharapkan dapat menggantikan penggunaan log book secara manual yang selama ini menggunakan kertas. Pengembangan ini juga diharapkan dapat memudahkan pihak pelabuhan perikanan dalam memperoleh data log book secara cepat dan akurat sehingga data tersebut dapat digunakan oleh stakeholder untuk mengelola sumber daya perikanan secara berkelanjutan.

Teknologi elektronik log book penangkapan ikan ini juga dapat diintegrasikan dengan Sistem Informasi Log Book Penangkapan Ikan (SILOPI) yang sudah dikembangkan oleh Ditjen Perikanan Tangkap, KKP dan diterapkan di pelabuhanpelabuhan perikanan. Melalui SILOPI ini, nelayan/ nakhoda kapal perikanan menyerahkan formulir log book (kertas) yang sudah diisi kepada petugas pelabuhan perikanan. Petugas pelabuhan kemudian 


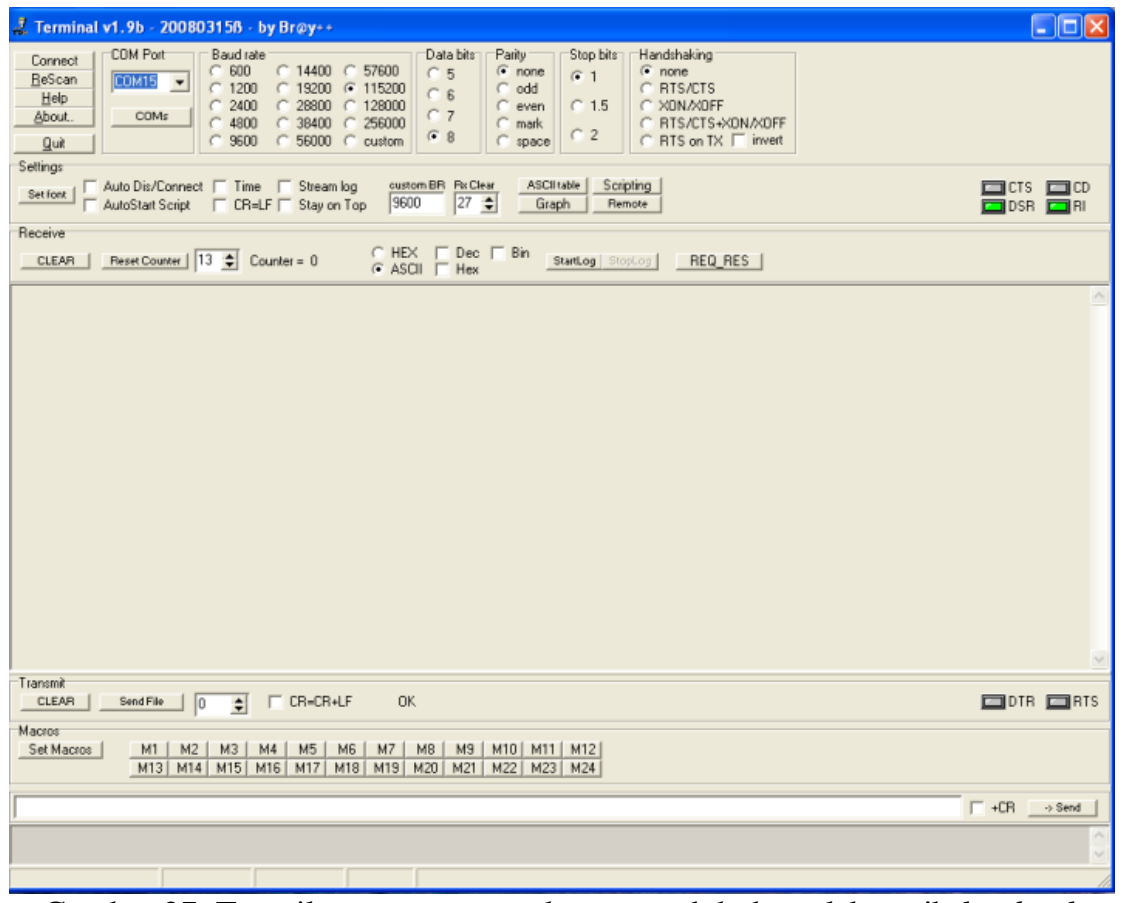

Gambar 27. Tampilan program untuk mengunduh data elektronik log book Figure 27. The display of program to download the data of electronic log book Sumber: Dokumentasi pribadi

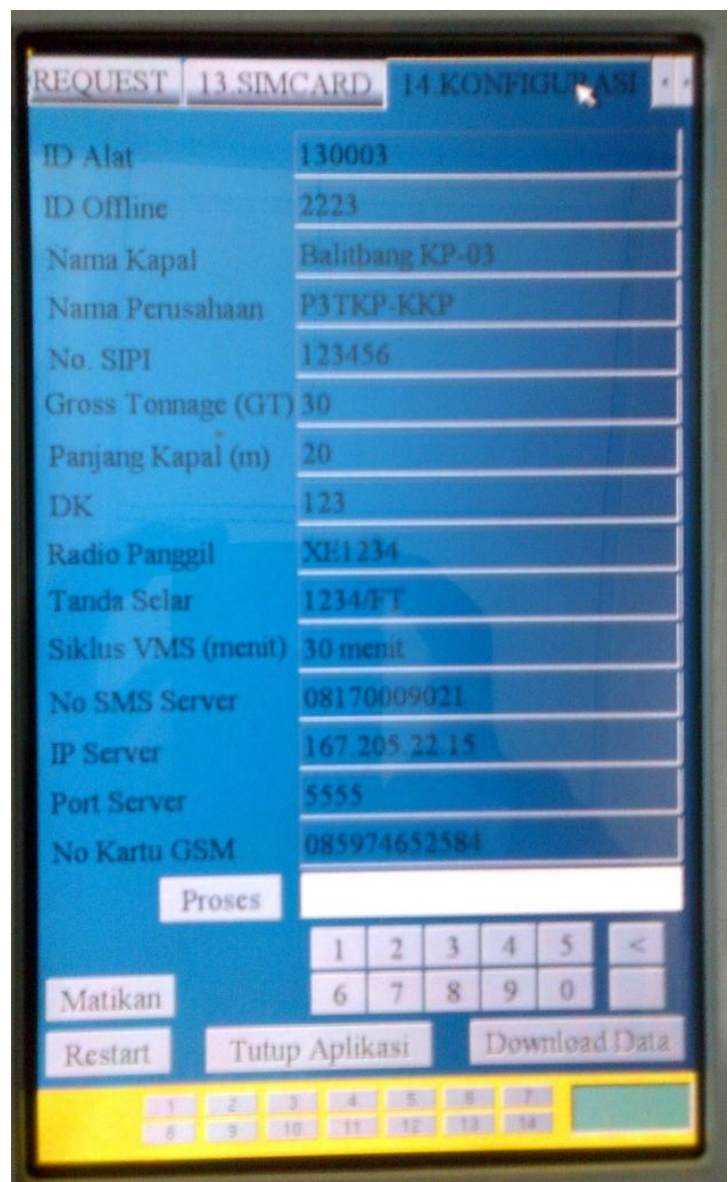

Gambar 28. Tampilan menu "Konfigurasi” pada elektronik log book. Figure 28. The display of "Konfigurasi" menu at electronic log book Sumber: Dokumentasi pribadi 


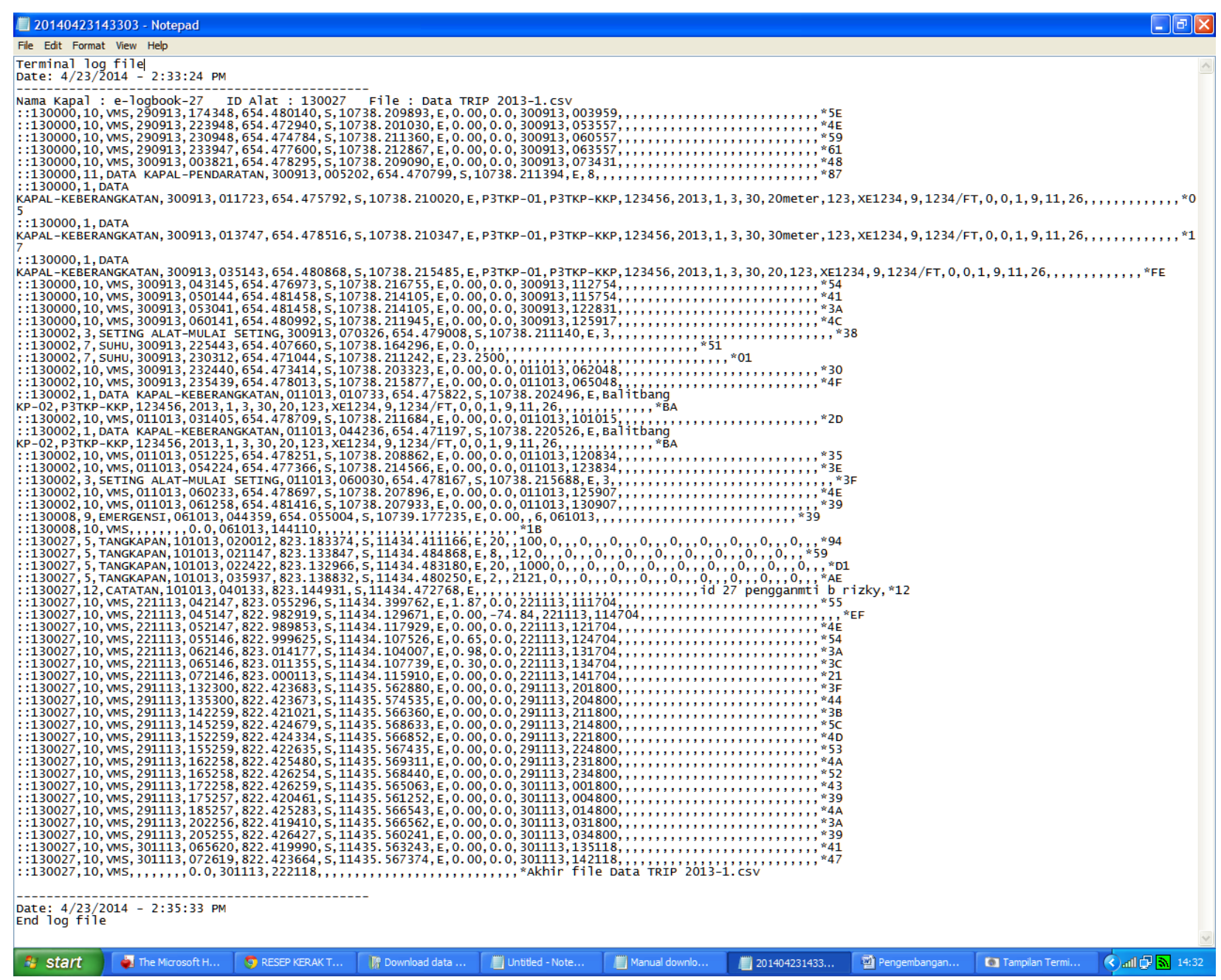

Gambar 29. Contoh data yang diunduh dari elektronik log book Figure 29. Examples of data downloaded from electronic log book Sumber: Dokumentasi pribadi

akan melakukan verifikasi terhadap data log book tersebut. Data log book yang sudah diverifikasi ini kemudian akan dimasukkan ke dalam SILOPI. Karena formulir log book dari nelayan jumlahnya banyak, maka proses input data ke dalam SILOPI juga membutuhkan waktu yang lama. Selain itu, juga ada kemungkinan petugas pelabuhan salah dalam memasukkan data ke dalam SILOPI. Apabila teknologi elektronik log book diintegrasikan dengan SILOPI, maka data dari elektronik log book dapat langsung masuk ke kolom-kolom di SILOPI secara otomatis sehingga petugas pelabuhan tidak perlu memasukkan data log book satu per satu ke dalam SILOPI. Petugas pelabuhan cukup melakukan verifikasi terhadap data tersebut. Hal ini dapat menghemat waktu, tenaga, biaya, serta mengurangi penggunaan kertas.

\section{KESIMPULAN DAN SARAN}

Telah dihasilkan perangkat keras elektronik $\log$ book penangkapan ikan berbasis layar sentuh, sebagai pengembangan elektronik log book P3TKP tahun 2011 dan 2012. Pengembangan tersebut adalah:

- Ukuran layar sentuh menjadi 7 inch.

- Penambahan pengisi baterai portabel (power bank) kapasitas 15000 mAh.

- Penggunaan antena GSM internal (dipasang di dalam perangkat keras).

- Sistem penyimpanan dan pengambilan data pada elektronik log book.

Hasil pengembangan elektronik log book ini sudah berhasil diuji diantaranya: penggunaan pengisi baterai portabel yang dapat menyimpan listrik 
selama 13 jam, pengiriman data menggunakan antena GSM internal berhasil dilakukan, serta data elektronik $\log$ book bisa diunduh dari alat dan disimpan di komputer.

Pengembangan perangkat keras ini diharapkan dapat memberikan kemudahan kepada nelayan dalam menggunakan elektronik log book sehingga diharapkan dapat menggantikan penggunaan log book kertas.

Teknologi elektronik log book penangkapan ikan ini juga dapat diintegrasikan dengan Sistem Informasi Log Book Penangkapan Ikan (SILOPI) yang sudah dikembangkan oleh Ditjen Perikanan Tangkap, KKP dan diterapkan di pelabuhanpelabuhan perikanan. Hal ini dapat menghemat waktu, tenaga, biaya, serta mengurangi penggunaan kertas.

\section{DAFTAR PUSTAKA}

Abidin, Z. H. (1995). Penentuan Posisi dengan GPS dan Aplikasinya. Jakarta: Pradnya Paramita.

Anonim. (2014). Arsitektur ARM. Diakses 3 Februari 2014 dari: http://id.wikipedia.org/wiki/ Arsitektur_arm.

Anonim. (2014). Pengisi Baterai Portabel. Diakses 3 Februari 2014 dari: http://id.wikipedia.org/wiki/ Pengisi_Baterai_Portabel.

Atmel Corporation. (2003). 8-bit AVR with 8 Kbytes InSystem Programmable Flash: ATmega8 ATmega8L. Diakses 9 April 2013 dari: http://www.alldatasheet.com/datasheet-pdf/ pdf/80247/ATMEL/ATMEGA8.html.

Dallas Semiconductor. (2013). DS 1820: 1-Wire Digital Thermometer. Diakses 20 Februari 2013 dari: http://www.alldatasheet.com/datasheet-pdf/ pdf/58548/dallas/ds1820.html.

Guangzhou FriendlyARM Computer Tech Co. Ltd. (2013). FriendlyARM Mini2440. Diakses 13 Desember $2013 \quad$ dari: http://www.friendlyarm.net/dl.php?file=mini244 $0 \_$overview.pdf.

Hadi, M.S. (2008). Mengenal Mikrokontroler AVR ATMegal6. Diakses 10 Juli 2013 dari: http://ilmukomputer.org/wp-content/uploads/ 2008/08/sholihul-atmega16.pdf.

Kourti, N., and Kotsakis, E. (2007). Electronic Logbook for Small Vessels (A Preliminary Study). European Commission - Joint Research Center Institute for the Protection and Security of the Citizen. Luxembourg. 13p.
Marzuki, M. I. (2011). Membangun elektronik log book perikanan untuk menunjang pengelolaan sumber daya ikan yang berkelanjutan. Bunga Rampai: Application of Sustainable Development Technology in Indonesia. Jakarta: Pusat Pengkajian dan Perekayasaan Teknologi Kelautan dan Perikanan. Pp. 53-59.

Marzuki, M. I. dan Nugroho, H. (2013). Rancang bangun elektronik log book perikanan berbasis GPRS untuk mendukung pengelolaan perikanan berkelanjutan. Prosiding Seminar Hasil Penelitian Terbaik Tahun 2013. Jakarta: Badan Penelitian dan Pengembangan Kelautan dan Perikanan. Pp 164-179.

Pusat Pengkajian dan Perekayasaan Teknologi Kelautan dan Perikanan. (2011). Rancang Bangun Elektronik Log Book Perikanan Berbasis GPRS. Laporan Akhir Kegiatan Penelitian. Kementerian Kelautan dan Perikanan, Jakarta.

Republik Indonesia. (2010). Peraturan Menteri Kelautan dan Perikanan No. PER.18/MEN/2010 tentang Log Book Penangkapan Ikan. Jakarta.

Shanghai SIMCom Wireless Solutions. (2011). SIM908 Hardware Design V1.00.

Sofyan, A. F. (2001). Teknologi layar sentuh menambah kenyamanan kios informasi. Jurnal Ilmiah DASI, 2(1), 42-47.

Syariman, P. (2012). Perkembangan dan Aplikasi Telemetri dalam Bidang Sumber Daya Air di Indonesia. Jakarta: Pusat Penelitian dan Pengembangan Sumber Daya Air, Badan Penelitian dan Pengembangan Kementerian Pekerjaan Umum. 44 hlm.

Willy. (2013). Layar Sentuh. Diakses 13 Desember 2013 dari: http://www.mdp.ac.id/materi/20122013-1/TI412/111068/TI412-111068-879-7.pdf. 
